DOI https:/ / doi.org/10.32837/app.v63i0.14

УДК 323.2:303.725.36

Милосердна I. М. ${ }^{*}(\mathrm{HУ} \mathrm{«ОЮА»)}$

ORCID: https://orcid.org/0000-0003-2083-9500

\title{
КОМУНІКАЦІЯ ТА ЗВОРОТНИЙ ЗВ'ЯЗОК У СТРУКТУРІ КІБЕРНЕТИЧНОГО МЕХАНІЗМУ ПОЛІТИЧНОГО УПРАВЛІННЯ
}

\section{COMMUNICATION AND FEEDBACK IN THE STRUCTURE OF CYBERNETIC MECHANISM OF POLITICAL GOVERNANCE}

*Iryna Myloserdna - PhD in Political Science, Associate Professor, Political Theories Department, National University "Odesa Law Academy" (23, Fontanska Doroha St., Odesa, Ukraine).

\section{Abstract}

The article researches the role of information for the realization of the cybernetic mechanism of political management, that is passed through communicative connections from the governing party to the governed one, and vice versa. An idea that communication takes place between two parties and for effective political management this communication should be bilateral, is analyzed and grounded. A presence of feed-back is the necessary condition of effective political management, as it gives an opportunity to see the connection of power (which operates in the state) and civil society.

The aim of the article is to analyze the role of communication and feedback in the structure of the cybernetic mechanism of political management in the conditions of democratic transformations.

The theoretical framework of the article is presented by the fundamental works of C. Shannon, N. Wiener, W. Ashby, H. Lasswell, B. Cretov, and others.

As the quality of information is determined by the level of development of civil society - id est society in that power depends on citizens and exists for citizens, but not vice versa. An exchange of political information is on a horizontal level between the members of society and organizations, and on a vertical level - between the various elements of the political system, it takes the more intensive place, thus attains the higher level of democracy in society. Thus a horizontal 
exchange has more important value, as oriented to the citizens for voices of that a fight is conducted.

One of the features of political management is the establishment of the leading role of information relations in the influence on guided. The cybernetic mechanism of political management pays attention to the general features and laws of transformation and motion of information due to communication channels. The presence of feedback is a prerequisite for the existence of political governance and its effective implementation, in particular.

Keywords: communication, political communication, feedback, political governance, democratic mode, civil society.

Постановка проблеми. Вивчення політичного управління викликано необхідністю пояснити процеси, які відбуваються як на міжнародній арені, так і в середині держави, в основному. Інформація, комунікація та зворотний зв'язок представляють собою не просто складові елементи політичного управління, але залежно від того, як вони реалізують в політичному управлінні та яка їх роль в цьому процесі, можна говорити й про ефективність здійснення політичного управління. Оскільки без своєчасної та достовірної інформації, комунікативного акту, особливо його політичного боку, а також зворотного зв'язку політичне управління буде здійснюватись або без позитивного результату, або може навіть носити деструктивний характер.

Метою дослідження $є$ аналіз ролі комунікації та зворотного зв' язку у структурі кібернетичного механізму політичного управління в умовах демократичних перетворень.

Аналіз основних досліджень та публікацій дає можливість стверджувати, що в сучасній науці існує значна кількість робіт, які присвячені вивченню феноменів комунікації, політики, політичної комунікації, проте майже відсутнім є досвід дослідження цих феноменів через призму політичного управління. Реалізацію поставленої мети слід розпочати з аналізу терміну «інформація», який був ведений відносно недавно, в середині XX століття К. Шенноном при застосуванні до теорії передачі кодів, яка отримала назву «Теорія інформації». В теперішній час наповнення цього терміну отримало більш глибокий природно-філософський зміст. Така трансформація - в сприйнятті людиною - поняття «інформація» стала наслідком трансляції та ретрансляції, сприйняття та перетворення того, що має загальну назву інформація. 
Між тим саме поняття «інформація» багато в чому залишається інтуїтивним та інтерпретується в різноманітних галузях життєдіяльності людини далеко неоднозначно. Різні дослідники по-своєму інтерпретують це явище і тому існує велика кількість визначень інформації, проте в усіх цих трактуваннях можна побачити спільні риси, які концентруються біля двох підходів, які отримали назви «атрибутивної» та «функціональної» концепцій інформації. При видовому підході до вивчення інформації інформаційні процеси розглядаються як різновид процесів, яким властиве відображення, а саме, як процеси, які відображаються і які властиві лише самокерованим (функціонально-кібернетичним) системам, при чому сама інформація інтерпретується як відображення, яке використовується в управлінні. Для другого, аспектного підходу, властивим є визнання інформації як відображеної різноманітності, інформація визнається атрибутивною властивістю всіх матеріальних об'єктів.

Для подальшого дослідження інформації доцільно розглянути еволюцію уявлень про неї. В такому разі необхідно зауважити, що вивчення інформації, як і управління, відбувалось на двох етапах: докібернетичному та кібернетичному.

Докібернетичне розуміння інформації як передачі повідомлень використовувалось більше двох тисячоліть - майже до середини XX сторіччя. Проте наукове пізнання вже на початку XX ст. змістовно поглибило поняття інформації, пов'язавши його з категорією відображення. Саме філософське розуміння категорії відображення як всезагальної властивості матерії виявилось методологічно плодотворним для проникнення до змісту інформації.

Ідея про те, що інформацію можна розглядати як дещо самостійне, виникла разом $з$ новою наукою - кібернетикою, яка довела, що інформація має безпосереднє відношення до процесів управління та розвитку, які забезпечують стійкість різноманітних систем. Сьогодні інформація розуміється як важлива субстанція чи середовище, яка живить дослідників, яка ними ж і створюється і безперервно оновлюється. Це була фундаментальна та разом з тим несподівана ідея.

Поставлена в один ряд 3 такими категоріями, як матерія та енергія, інформація перетворилась в неймовірно широке поняття та продовжувала розкриватися все ширше та глибше. Залежності від галузі, в якій проводилось дослідження, інформація отримувала велику кількість визначень: інформація - означення змісту, який отриманий від зовнішнього світу під час пристосування до нього 
(Н. Вінер); інформація - заперечення ентропії (Л. Бриллюен); інформація - комунікація та зв' язок, під час якої усувається невизначеність (К. Шеннон); інформація - передача різноманітності (У. Ешбі); інформація - оригінальність, новизна; інформація - міра складності структур (А. Моль). Кожне з цих визначень розкриває ту чи іншу сторону цього багатозначного поняття (Всемирная энциклопедия: Философия, 2001, с. 429).

Проте особливу увагу інформації приділяють в кібернетиці, де питання вироблення, зберігання та передачі інформації відіграють у цій науковій галузі провідну роль. Крім цього, необхідно звернути увагу на те, що однією з ідей кібернетики є думка про єдність процесів зв' язку та процесів управління. А під зв'язками в кібернетиці розуміють інформаційні зв'язки, які здійснюються певними інформаційними процесами. У такому разі можна говорити про провідну роль інформації в кібернетиці. 3 точки зору кібернетики, процес політичного управління, його кібернетичних механізм представляє собою, перш за все, процес циркуляції інформації між керованими та керуючими об'єктами.

Що ж стосується вивчення розвитку інформаційних засобів та систем, а також характеру, форми й результату їх взаємодії на суспільне життя та політичну сферу, зокрема, то цим феноменом займається комунікативістика. Крім цього, розуміння ролі комунікацій у політичному управлінні, а також ролі політичних комунікацій дає змогу говорити про здійснення ефективного політичного управління.

При розгляданні комунікацій необхідно також не забувати про те, що передача певної інформації від суб'єкта до суб'єкта може бути не одновекторною, тобто, як було зазначено, утримувач інформації може ії переосмислити і таким чином вже нову інформацію передати назад. У такому разі можна говорити про наявність зворотного зв' язку. Зміст цього принципу полягає в тому, що кожний наступний вплив на керуючий об'єкт визначається на основі відомостей про результати попереднього впливу - прикладаючи до класу явищ, які відносяться до окремих видів цілеспрямованої діяльності, об'єднаних загальним поняттям «комунікація». Особливе значення це явище має при дослідженні процесів управління, в тому ж числі й політичного управління. «Встановлюючи зв'язок з іншою особою, - відзначав 3 цього приводу Н. Вінер, - я повідомляю йому сигнал, а коли особа в свою чергу встановлює зв'язок зі мною, вона повертає подібний сигнал, який містить інформацію, яка в першу чергу доступна для 
нього, а не для мене. Керуючи діями іншої особи, я передаю йому сигнал, та, хоч цей сигнал наданий в імперативній формі, техніка комунікації в даному випадку не відрізняється від техніки комунікації при повідомленні сигналу факту. Більше того, щоб управління було дійсним, я повинен спостерігати за будь-якими сигналами, котрі надходять від нього, а також тими, котрі можуть вказувати, що наказ прийнятий та виконується» (Винер, 19833, 46). Таке розуміння комунікації в черговий раз доводить, що управління представляє собою приватний випадок комунікації.

Проте таке розуміння взаємодії управління та комунікації не можна вважати остаточним. Оскільки комунікація представляє собою ще й якісну характеристику політичного управління, під яким ми розуміємо суб'єкт-об'єктні відносини, які пов' язані між собою владою (владними відносинами) та зворотним зв' язком. У такому разі й саме окремий випадок комунікації (ії політичної специфіки), що допускає наявність зворотного зв' язку, $є$ не що інше, як політичне управління, що включає в себе і так званий «політичний діалог», який, як було показано вище, завжди містить у собі в прихованому вигляді управлінські моменти.

Як було згадано вище, процес комунікації здійснюється через суб'єкти, між зв'язками, які виникають в них і які беруться як певна єдність, отже в певному значенні вони розглядаються як система цих взаємовідносин, які мають властивості змінювати свій стан (руйнуватися або оновлюватися). Коли ж перенести це визначення до політичного контексту, то можна сказати, що в політичній системі (під якою ми розуміємо певний взаємозв' язок суб'єктів політики та організації відносин між ними, а також політична діяльність у суспільстві), політична комунікація розуміється як процес передачі політичної інформації в системі, а також зв'язок між системою та суспільством. Завдяки цьому процесу інформація циркулює від однієї частини політичної системи до іншої. Йде безперервний процес обміну інформацією між індивідами та групами на всіх рівнях. I саме таке ії розуміння представляється актуальним і для політичного управління, оскільки тут ми здійснюємо процес комунікації, який передбачає передачу інформації 3 метою врахування наявних тенденцій, які можуть впливати на перебіг політичного управління та його результативність для держави.

Таким чином, вже починаючи $з$ цього моменту маємо право говорити про суто політичні комунікації, які сьогодні відіграють провідну роль в суспільстві та політичному управлінні. Витоки 
сучасних уявлень щодо розуміння політичних комунікацій сягають своїм корінням до античних часів, коли ще Аристотель звернув увагу на комунікації, які відігравали важливу роль у політичній діяльності і які він розглядав як процес «спілкування», спрямований на досягнення вищого «суспільного блага» (Аристотель, 1983, 132).

При подальшому дослідженні ролі комунікації та зворотного зв' язку в політичному управлінні доцільно приділити увагу розгляду основних уявлень про політичні комунікації. Серед вчених, які в свою чергу доповнювали й розвивали вивчення ідей у галузі політичної комунікації, можна назвати Г. Лассуелла, Шеннона-Уівера, Ж.-М. Котре, Л.С. Санистебана, Й. Боровика, Б. Ван Каама.

Вагомий внесок у розуміння політичної комунікації та інформаційнокомунікативної моделі політичної системи взагалі, саме яка дає можливість говорити про існування політичної кібернетики (політичного управління як процесу, отримання та перетворення інформації в кібернетичних системах), вніс К. Дойч. Він назвав політичну комунікацію «нервовою системою державного управління», вважаючи політичні повідомлення чинником, який обумовлює політичну поведінку.

На думку Ж.-М. Коттре, роль комунікації в політичному житті суспільства можна порівняти зі значенням кровообігу для організму людини (Эшби, 1959, 9, 112). 3 таким же успіхом ії можна назвати «джерелом життєвої сили» або «материнським молоком» політики, тому що політична комунікація є необхідною субстанцією, яка пов'язує воєдино різні частини суспільства і дозволяє їм функціонувати в якості єдиного цілого. Політичні повідомлення, що циркулюють у суспільстві, породжують уявлення, які визначають сутнісну і якісну сторони політичного життя.

Виходячи зі сказаного вище можна говорити, що поняття «політична комунікація» пройшло певний розвиток, перш ніж ми почали говорити про неї як про процес передачі політичної інформації, за допомогою якого інформація циркулює між різними елементами політичної системи, а також між політичною й соціальною системами. Тут ми можемо зауважити, що політична комунікація $є$ своєрідним соціально-інформаційним показником політики, який представляє собою процеси передачі, обміну політичною інформацією, яка структурує політичну діяльність і надає їй нового значення.

Під політичною комунікацією розуміється «...обмін інформацією між суб'єктами політичного життя, а також між державою і громадянами», який «може протікати на формальному (наприклад, в засо- 
бах масової інформації) і неформальному («закулісні»переговори) рівнях» (Латынов, 1999, 172-173).

На думку Б.С. Кретова, політична комунікація представляє собою процес передачі політичної інформації, завдяки якому вона циркулює від однієї частини політичної системи до іншої і між політичною системою та соціальною системою. Йде безперервний процес взаємообміну інформацією між індивідами та групами на всіх рівнях.

Особливе місце в політичній комунікації посідає обмін інформацією між правителями і керованими 3 метою домогтися їхньої згоди. Дійсно, будь-який правитель прагне домогтися згоди з його рішеннями, а кожен керований намагається висловити свої потреби і домогтися, щоб про них дізналися.

Також необхідно звернути увагу на роль політичної комунікації в громадянському суспільстві та політичному управлінні.

Оскільки якість інформації визначається рівнем розвитку громадянського суспільства - тобто суспільства, в якому влада залежить від громадян й існує для громадян, а не навпаки. Обмін політичною інформацією на горизонтальному рівні між членами суспільства й організаціями, та на вертикальному рівні, між різноманітними елементами політичної системи відбувається тим інтенсивніше, чим досягнуто вищого рівня демократії в суспільстві. При цьому горизонтальний обмін має більш важливе значення, оскільки орієнтований на громадян, за голоси яких й ведеться боротьба.

Слід також пам'ятати, що у механізмі здійснення політичного управління одне з провідних місць належить прийняттю політичних рішень. Для вироблення і прийняття правильних політичних рішень необхідно відповідне інформаційне забезпечення органів політичної влади. Таким чином, інформація та ï передача є невід'ємним фактором управління. Вона відображає процес функціонування і розвитку об'єкта управління, його внутрішній стан, зовнішні умови і цілі управління.

В рамках політичного управління інформацію розглядаємо лише як певну сукупність різних повідомлень, відомостей, даних про відповідні предмети, явища, процеси, відносини та ін. Ці відомості, будучи зібраними, систематизованими і перетвореними в придатну для використання форму, відіграють в управлінні виняткову роль (Закупень, 1997, 38).

Крім того, як слушно відзначають А.А. Нурмагамбетов та Є.К. Аліяров, володіння інформацією в сучасному суспільстві 
$€$ найважливішим джерелом влади. Політичне управління здійснюється крім іншого за допомогою інформації. Інформаційна влада все більше вторгається в усі сфери суспільних відносин, набуваючи в деяких випадках самостійного значення.

Таку ж думку висловлює доктор політичних наук М.Н. Грачов: «...політичну комунікацію сьогодні з усією очевидністю необхідно визнати одним з найважливіших аспектів легітимації влади» (Грачев, $2005,3)$. Справді, якщо раніше керування розглядалося як засіб, за допомогою якого керуючі віддають накази керованим, то зараз багато дослідників прийшли до висновку, що комунікація відповідає фундаментальним потребам політичної системи, тобто забезпечує порозуміння між керівниками і керованими.

Отже, однією із особливостей політичного управління є встановлення провідної ролі інформаційних відношень у керованому впливі. Саме в кібернетичному механізмі політичного управління приділяється увага загальним особливостям та законам перетворення та руху інформації завдяки каналам зв'язку. Тут мова йде про існування інформаційних зв'язків, обмін інформацією, що представляє собою одну зі змістовних сторін єдності функціонування суспільства. Найкраще зрозуміти інформаційну систему допомагає зворотній зв' язок.

Перш ніж вивчати зворотний зв' язок, як у сучасному політичному управлінні, так і в політичному процесі взагалі, доцільно визначити зміст цього поняття. При розгляді зворотного зв' язку, автори звертають увагу на природу походження даного принципу. Так, прийнято вважати, що дослідження в області зворотного зв'язку проходять 3 двох сторін. 3 одного боку, з точки зору його ролі в кібернетиці, а з іншого - ролі даного принципу в комунікативному аспекті. При дослідженні зворотного зв'язку в даній статті звертається увага саме на кібернетичному тлумаченню, тобто з точки зору його ролі в управлінському аспекті.

Таким чином, першочерговим є визначення змісту поняття «зворотний зв' язок». Якщо розглядати зворотний зв' язок в найзагальнішому вимірі, можна говорити, що головне завдання даного зв'язку полягає в доведенні відомостей керуючої системи про все, що відбувається у керованій системі.

Проте необхідно брати до уваги, що зворотний зв'язок, як і управління, розглядають виходячи $з$ двох аспектів: інформаційного і кібернетичного. 
Першим пояснити принцип зворотного зв'язку спробував Н. Вінер, який у загальному вигляді під ним розумів кожний наступний вплив на керований об'єкт, при цьому враховувалася вже наявна інформація. Так, Н. Вінер звертає увагу на вивчення ролі даного зв'язку в управлінському процесі, а вже надалі ми маємо право повною мірою говорити також про його роль у політичному управлінні. Як було зазначено, Н. Вінер розумів під зворотнім зв' язком здатність під час встановлення зв' язку між собою повідомляю йому сигнал, а коли людина, в свою чергу встановлює зв'язок у відповідь, вона повертає подібний сигнал, який містить інформацію, яка в першу чергу доступна для нього, а не для мене. Керуючи діями іншої людини, таким чином, я повідомляю йому сигнал, але хоча цей сигнал надано в імперативній формі, техніка комунікації в даному випадку не відрізняється від техніки комунікації при повідомленні сигналу факту. Більше того, щоб управління було дійсним, необхідно спостерігати за будь-якими сигналами, які надходять від нього, а також які можуть вказувати, що наказ прийнятий і виконується. Виходячи 3 цього, ми можемо говорити, що при такому розумінні зворотного зв'язку Н. Вінер вкладав у зміст даного поняття й інформаційний аспект. Крім цього, Н. Вінер розумів зворотний зв'язок, як «посох сліпого», «секрет життя», як фундаментальну основу не тільки в машинах, живій природі, а й у соціальному середовищі, яке становить особливий інтерес. При цьому слід зауважити, що зворотному зв'язку часто відводиться лише роль інформування, передачі певної інформації про здійснення основних завдань управлінського процесу. Так, С. Бір визначає «зворотний зв'язок» як повернення інформації на ії початок, яка надалі змінюється.

У кібернетиці, як вказує Л.А. Петрушенко, під зворотним зв'язком слід розуміти «зв'язок між керованим і керуючим пристроєм для передачі осведомітельной (або контролюючої) інформації від керованого пристрою до керуючого і разом з тим один з елементів управління із зворотним зв' язком» (Петрушенко, 1967, 28). Таке визначення зворотного зв' язку дозволяє виділити кібернетичну специфіку розуміння управління.

На думку автора треба звернути увагу на те, що спочатку здійснення принципу зворотного зв'язку було практично покладено на плечі держави, яка являє собою не тільки форму громадського об'єднання людей у конкретному просторі, яке спирається на владу, право, цінності, але й як певна комунікаційна ланка, канал між 
владою і суспільством, при чому така взаємодія здійснювалося у двох напрямках. Однак у зв' язку з ускладненням життя з'являються нові інститути, які представляють та захищають інтереси різних верств населення, виникає потреба у створенні більш ефективної системи взаємодії влади і громадян на різних рівнях.

Слід зазначити, що особливо актуальним це питання є для держав, у яких відбувається зміна режиму, соціодинаміка політичних систем (наприклад, країни Центрально-Східної Європи, Росія й Україна в тому числі). При цьому цікавим є той факт, що така взаємодія найчастіше ініціюється рядовими членами суспільства, які представляють собою певну самоорганізацію громадян. Саме остання $\epsilon$ основою реалізації інтересів громадян, а від того, як дана самоорганізація забезпечується суспільством і державою, залежить і розвиток самого громадянського суспільства. А в сучасному світі найкраще простежити принцип зворотного зв'язку можна виходячи з оцінки взаємозв' язку держави і громадянського суспільства.

Необхідно брати до уваги, що зворотний зв' язок може проявлятися на двох рівнях. 3 одного боку - на рівні взаємодії між владними структурами (центральними та регіональними органами), а з іншого, як зазначалося вище, - на рівні взаємодії держави і громадянського суспільства. У такому разі порушення чітко прописаної процедури зворотного зв' язку в першому випадку може мати такі наслідки, як гальмування розвитку держави, а в другому - втрату рівня довіри громадян до існуючої влади.

Разом з тим, існують випадки, коли зворотній зв' язок носить прихований характер, і особливо це характерно для тих відносин, в яких немає чіткої підзвітності та суворої структури розвитку взаємовідносин. При використанні такого зворотного зв'язку політична влада в такому випадку приховує, особливо від громадян, свої дії повністю або намагається якимось чином перебільшити підсумки своєї діяльності, при цьому не відображаючи реальну картину. Однак, слід зазначити, що це не тільки є негативним у прихованому зворотному зв'язку в політичному управлінні, але в такому разі й саме управління може постраждати від цього. Мається на увазі, що органи гілок політичної влади, таким чином, можуть не побачити реальні промахи своєї діяльності, що в свою чергу буде шкодити стабільному розвитку держави.

В політичному управлінні зворотний зв'язок також має певні властивості. Тут мова йде про його інтенсивність та жорсткість. Щодо 
інтенсивності, то тут мається на увазі вплив керованих на керуючих і провідну роль в таких відносинах, як зазначалось раніше, відіграє негативний зворотній зв' язок, який, таким чином, стає запорукою стабільного розвитку демократичної держави, а значить й політичного управління в ній.

Що ж стосується жорсткості зворотного зв'язку, то вона, перш за все, пов' язана безпосередньо з реалізацією основних цілей, зазначених владою та прийняттям політичних рішень, що є запорукою ефективного здійснення політичного управління. Жорсткість зворотного зв'язку піддається регулюванню, яке можна побачити в таких діях. По-перше, зміні міри відповідальності депутата своєму електорату, який має відбуватися періодично, а не лише під час передвиборчої кампанії. По-друге, така звітність передбачається й на рівні дії гілок політичної влади: підзвітність виконавчій владі парламенту. Таким чином, яскравим прикладом здійснення зворотного зв' язку в сучасній демократичній державі є вибори, які показують рівень довіри громадян до чинної влади та до їх стилю політичного управління.

Отже, однією з умов здійснення ефективного кібернетичного механізму політичного управління $є$ наявність в ньому відкритої, своєчасної та дійсної інформації, комунікативних зв' язків між суб'єктом та об'єктом політичного управління, під час яких сторони мають змогу обмінюватися інформацією в двосторонньому напрямку. Наявність зворотного зв' язку є необхідною умовою існування політичного управління та його ефективного здійснення, зокрема.

\section{Лimepamypa:}

Аристотель (1983). Политика. Сочинение 8 4-х m. М.: «Мысль» Бир С. (1965). Кибернетика и управление производством. М.: Наука Винер Н. (1983). Кибернетика, или управление и связь в животном и машине; пер. с англ. И. В. Соловьева и Г. Н. Поварова; под ред. Г. Н. Поварова. M.: Наука. <www.polsci.chula.ac.th/pitch/planningtheory2009/ lindblom.pdf>

Всемирная энииклопедия: Философия (2001). Главн. науч. ред. и сост. А. А. Грицанов. М.: АСТ, Мн.: Харвест, Современный літератор.

Грачев М. Н. (2005). Политическая коммуникация: теоретикометодологический анализ: автореф. дис. на соискание научной степени д-ра полит. наук.: спец. 23.00.01 «теория политики, история и методология политической науки. М., 2005. 
Закупень Т. (1997). Качественные аспекты информации в органах государственного управления. Проблемы теории и практики управления, $6,38-42$.

Латынов В. В. (1999). Политическая коммуникация. Политическая эницклопедия: В 2 m. М.: Мысль, 172-173.

Петрушенко Л. А. (1967). Принцип обратной связи. (Некоторые философские и методологические проблемы управления). М.: Мысль, Шеннон К. (1963). Работы по теории информации и кибернетике. М.: Иностранная литература.

Эшби У. Р. (1959). Введение в кибернетику. М.: Иностранная литература. Cotteret J.-M. (1973). Gouvernants et gouvernes: La communication politique. Paris: Presses universitaires de France.

Lasswell H. D. (1948). The Structure and Function of Communication in Society. The Communication of Ideas, 37-51.

\section{References:}

Aristotel (1983). Politika. Sochineniye v 4-kh t. [Politics. Composition in 4 vols.]. M.: «Mysl». [in Russian].

Bir S. (1965). Kibernetika i upravleniye proizvodstvom [Cybernetics and production management]. M.: Nauka. [in Russian].

Cotteret J.-M. (1973). Gouvernants et gouvernes: La communication politique [Governors and Governes: Political Communication]. Paris: Presses universitaires de France. [in French]

Eshbi U. R. (1959). Vvedeniye v kibernetiku [Introduction to cybernetics]. M.: Inostrannaya literatura. [in Russian].

Grachev M.N. (2005). Politicheskaya kommunikatsiya: teoretiko-metodologicheskiy analiz: avtoref. dis. na soiskaniye nauchnoy stepeni d-ra polit. nauk.: spets. 23.00.01 «teoriya politiki. istoriya i metodologiya politicheskoy nauki [Political communication: theoretical and methodological analysis: author. dis. for the degree of Dr. polit. sciences.: special. 23.00.01 "The theory of politics, history and methodology of political science]. M.. 2005. [in Russian].

Lasswell H. D. (1948). The Structure and Function of Communication in Society. The Communication of Ideas, 37-51.

Latynov V. V. (1999). Politicheskaya kommunikatsiya. Politicheskaya entsiklopediya: V 2 t. [Political Communication. Political Encyclopedia: In 2 vols.].M.: Mysl. 172-173. [in Russian]. 
Petrushenko L. A. (1967). Printsip obratnoy soyazi. (Nekotoryye filosofskiye $i$ metodologicheskiye problemy upravleniya) [Feedback principle. (Some philosophical and methodological problems of management)]. M.: Mysl. [in Russian].

Shennon K. (1963). Raboty po teorii informatsii i kibernetike [Works on information theory and cybernetics]. M.: Inostrannaya literatura. [in Russian].

Viner N. (1983). Kibernetika. ili upravleniye $i$ svyaz $v$ zhivotnom $i$ mashine [Cybernetics, or control and communication in the animal and machine]; per. s angl. I. V. Solovyeva i G. N. Povarova; pod red. G. N. Povarova. M.: Nauka. [in Russian].

Vsemirnaya entsiklopediya: Filosofiya [World Encyclopedia: Philosophy] (2001). Glavn. nauch. red. i sost. A. A. Gritsanov. M.: AST. Mn.: Kharvest. Sovremennyy literator. [in Russian].

Zakupen T. (1997). Kachestvennyye aspekty informatsii v organakh gosudarstvennogo upravleniya [Qualitative aspects of information in government]. Problemy teorii i praktiki upravleniya [Problems of theory and practice of management], 6, 38-42. [in Russian].

\section{Анотація}

Милосердна І.М. Комунікація та зворотний зб'язок у структурі кібернетичного механізму політичного управління. - Стаття.

Стаття присвячена дослідженню сутності комунікації та зворотного зв'язку та визначенні їх ролі у здійсненні політичного управління $b$ сучасній демократичній державі з розвиненим громадянським суспільством. Обгрунтовується роль інформації для здійснення кібернетичного механізму політичного управління,яка передається через комунікативні зв'язки від керуючої сторони до керованої та навпаки. Аналізується та обгрунтовується думка, щзо комунікація відбувається між двома сторонами і дяя ефективного політичного управління необхідно, аби ияя комунікація була двосторонньою. Наявність зворотного з' язку є необхідною умовою ефективного політичного управління, оскільки дає змогу побачити зв'язок влади (що діє в державі) та громадянського суспільства.

Ключові слова: комунікачія, політична комунікація, зворотний зb'язок, політичне управління, демократичний режим, громадянське суспільство. 